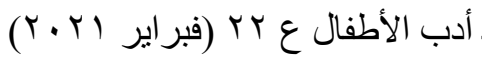
و اجبات الو الدية الصالحة

\title{
واجبات "الوالاية الصالحة" في ضوء المنظور القرآني
}

\author{
د. حسان عبد الله حسان
}

أستاذ أصول التربية المساعد- جامعة دمياط

\section{ملخص البحث}

يتناول البحث الحالي موضوع "الو الدية الصالحية" في المنظور القر آني، وتحديدًا ما يتعلق بواجبات هذه الوالدية كما تضمنتها البيئة القرآنية، والتي وقفنا فيها على تسعة لئل واجبات هي: - 20 - 20

أولاً - و واجب الحماية الوجودية.

ثانيًا - و واجب الحماية الأخلاقية.

ثالثًا - و واجب الحماية الاجتماعية.

رابعًا - واجب البناء الجسدي.

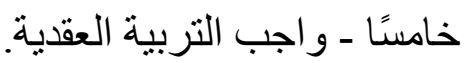

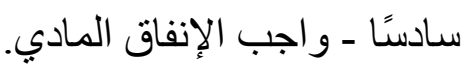

سابعًا - واجب تنمية القابليات العقلية.

ثامنًا ـ و واجب التربية الجنسية.

تاسعًا ـ الوقاية من الانحر افات الجنسية.

\section{مقدمة البحث وأهميته}

تنظر منظومة القيم القرآنية إلى أعضاء الأسرة الجدد الناتجين عن عملية الزواج

(الأطفال- الأبناء) باعتبار هم حلقة من حلقات الجنس البشري، المحافظين على استمراره،

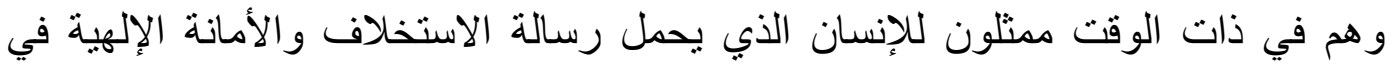
الأرض، ومن ثم تتجاوز النظرة القرآنية، تلك النظرات الوضعية التي نرى في نتاج عملية

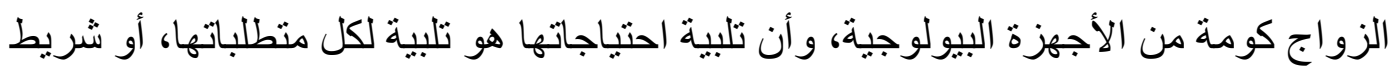




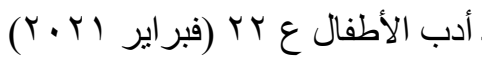
و اجبات الو الدية الصالحة

كاسيت أو اسطوانة كمبيوتر أو هارد، كل مههة الوالدية ملأى بالمعارف الضرورية و اللازمة لتلبية تلك الاحتياجات ومتطلباتها، فحقيقة النظرة القر آنية هي غاية الخلق نفسه: من الإعمار ، والتزكية، والهداية، والفلاح، "إن الهدف الرئيس للوالدية هو إثمار خلفاء أهل للثقة، رسالتهم في الحياة هي الإعمار ، وتحصيل الفلاح في الدنيا والآخرة"('). فالوالدية تقوم بإعداد أبناؤها من أجل تحقيق وظيفة كبرى يتعاون فيها الجنس البشري كله، وتؤهله للقيام بذلك الدور بالتعاون و التكامل مع أقرانه "إن وظيفة الأسرة في رعاية أفرادها وتكامل أدوارهم هو الأساس الفطري الحيوي والنفسي لعلاقات أفراد الأسرة الإنسانية، و عدم إدراك المبدأ الإسلامي في تكامل أفراد الجنس البشري عامة، و أدوار أعضاء الأسرة بشكل خاص - يؤدي إلى عدم فهم بناء الأسرة المسلمة، و عدم إدر الك أدوار كل عضو فيها. إن التوافق و التكامل اللذين يحققان التعاون و الرعاية و الود و الرحمة بين الأبوين - الزوج و الزوجة ـ هو الأساس الذي تُبنى عليه الأسرة الإنسانية وذلك حتى يحظى الطفل بالسلام و الأمن و الر عاية و التربية الضرورية لبنائه النفسي و المعرفي القويم"(؟). من الو اجبات الو الدية في بناء الطفولة تحقيق عدة مقاصد رئيسة، أهمها مقصد تأمين فضاء التنشئة الاجتماعية للطفولة، حيث إن الأجواء السائدة في الأسرة وطبيعتها في مؤسسة الزواج هي المسئولة عن إنتاج النوع البشري، و إعداده وتربيته، وباستقرار هذه المؤسسة يستقر المجتمع وباضطر ابها بضطرب، ومن هنا فقد أكدت الثريعة الإسلامية في بناء

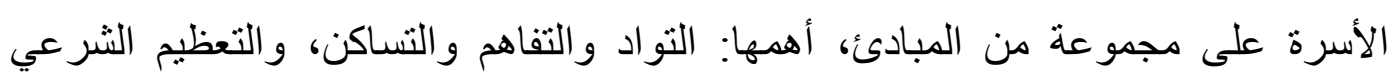

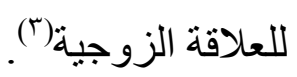
وفي ضوء ذلك فإن الو الدية عليها واجبات أصيلة تحتاج في إطار تحقيقها إلى رسم خارطة لهذا البناء الاستخلافي لأبنائها، خارطة بحسب مراحل الاحتياجات والمتطلبات: خارطة قريبة المدى، وخارطة منوسطة المدى، وخارطة بعيدة المدى، وفي كل مرحلة هدف و مقصد و إجر اء ووسائل، نحو تحقيق الغاية الكبرى التي أوكلت إليها. إن الوالدية الجيدة استثمار طويل الأجل، وهو مفتاح النجاح في التنمية الوجدانية و النفسية والبدنية للأطفال. وجوهر الوالدية الصالحة هو توفير بيئة حب دافئة يزدهر فيها

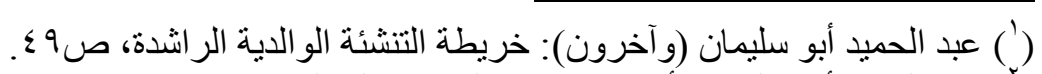

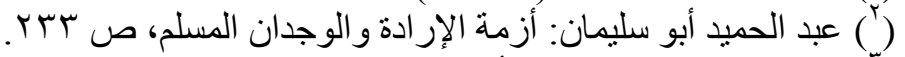

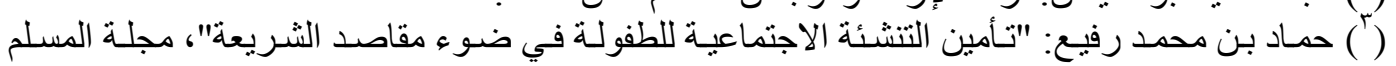

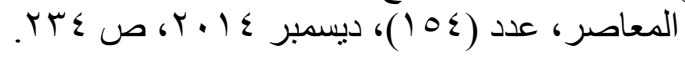




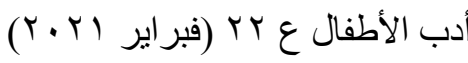
و اجبات الو الدية الصالحة

الطفل، وتتشكل العلائق التي تحقق المعية والاتصال الجمعي القائم على تنمية الاتجاهات الإيجابية و الطموح لدى النشء. ومن ثَمَّ فعلى الولدين الوعي بالهدف الرئيس لعملية التنشئة في الأسرة، وهو: تنشئة الطفولة السوية. و الو الدان هما المكلفان بتلك المهمة. وطريق الوالدية الصالحة ليس وصفة جاهزة، بل هو تحت الإنشاء المستدام. وهو قابل للتحسين على الدوام بالصبر و التدرج السنني في تللك العملية('). الثكل التالي يوضح أهم واجبات الوالدية الصالحة، وفقًا للبيئة القر آنية التي تتاولت

أبعاد تلك الو اجبات.

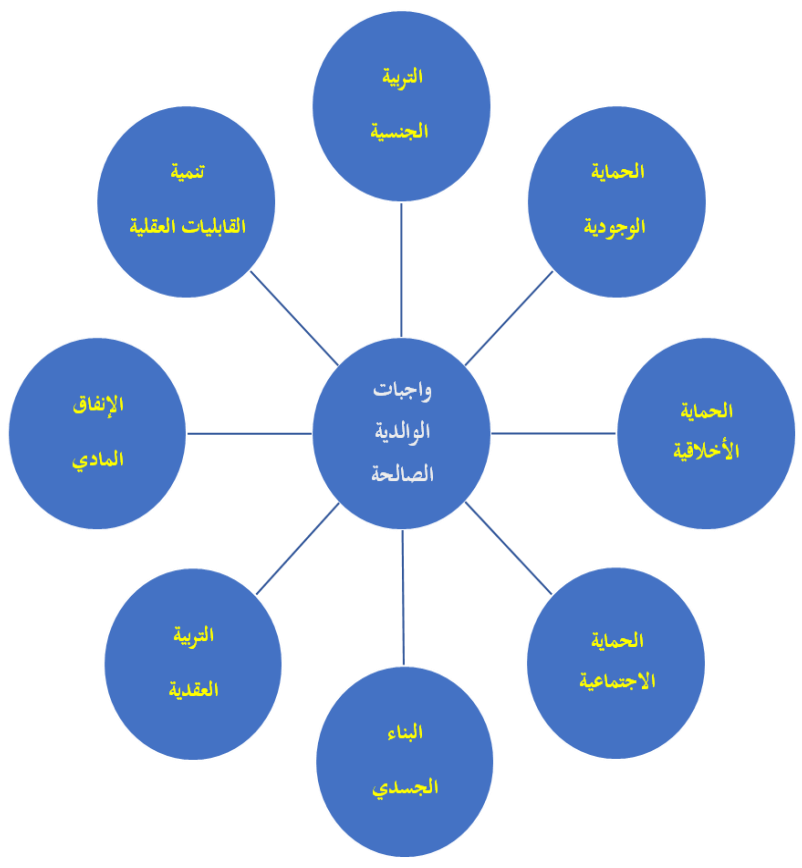

شكل (1)

واجبات الوالدية الصالحية في البيئة القرآنية

أولاً - واجب الحماية الوجودية

تتضمن منظومة القيم القرآنية في هذا الجانب مقصدًا أساسيًا لهذا الواجب، هو حفظ حياة الطفل، وتوفير المناخ الملائم لإيجاده في الحياة، وفي ذلك تتحدث البيئة القر آنية عن هذا

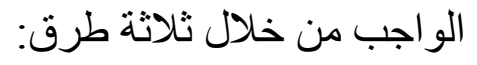

(') عبد الحميد أبو سليمان (وآخرون): خريطة التنشئة الو الدية الراشدة، مرجع سابق، صع r. 


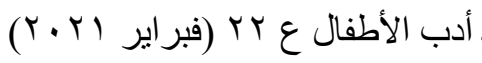

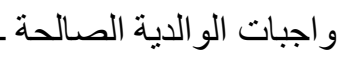

\section{الطريق الأول: تحريم قتل النفس عامة، أو الإضرار بها}

إن مقصد حفظ الحياة عام في الثريعة، يخص كل النفس عمومًا، فمن الضرورات

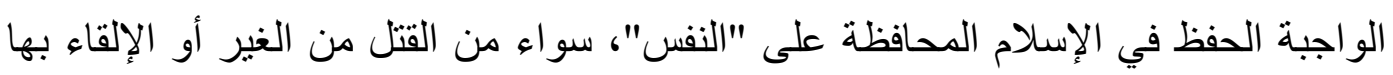

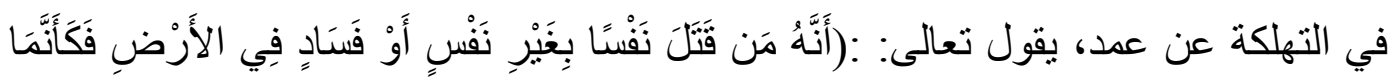

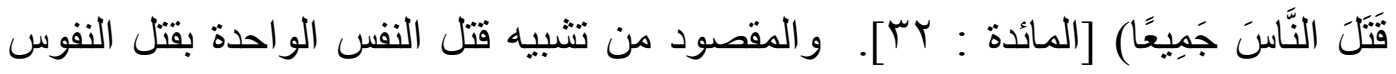

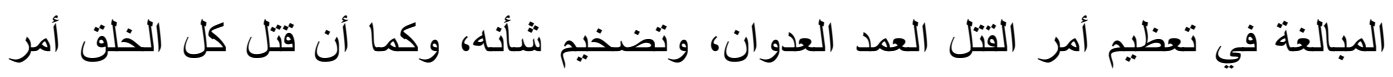

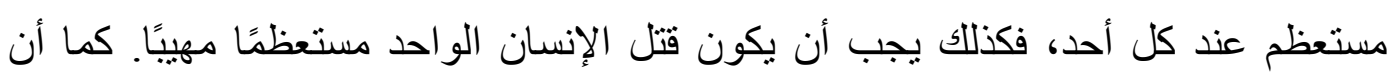

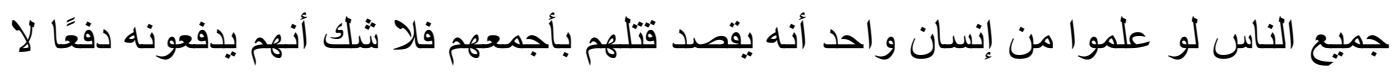
يمكنه تحصيل مقصوده، فكذلك إذا علموا منه أنه يقصد قتل إنسان واحد معين يجب أن أن يكون جدهم و اجتهادهم في منعه عن قتل ذللك الإنسان مثل جدهم واجتهادهم في الصورة الأولى (1).

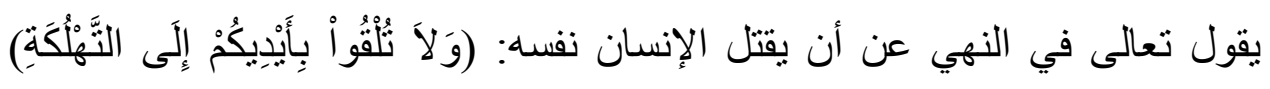

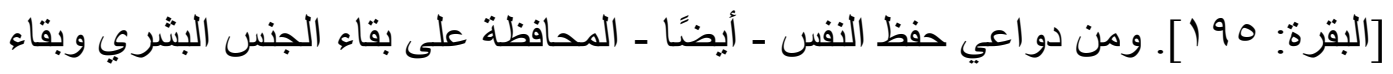

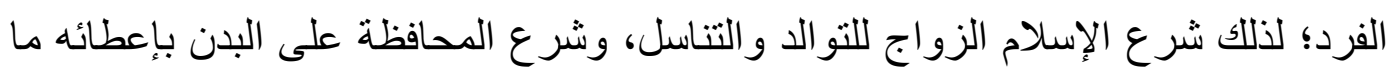

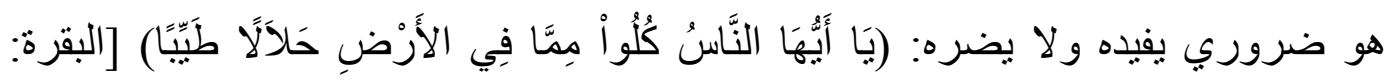

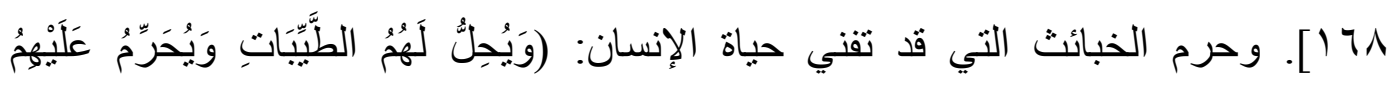

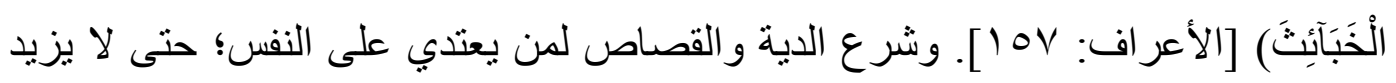

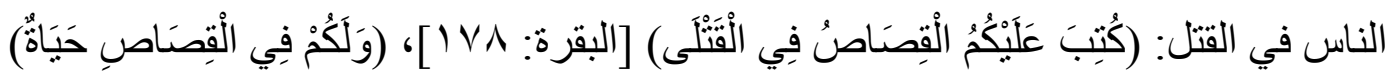

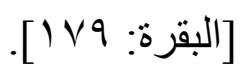

\section{الطريق الثاني: تحريم قتل الأولاد خوف الفقر، أو بسبب النوع}

كما أكد الوحي على تحريم ذللك ـ قتل النفس - بصورة أخص على "الأبناء"- و إن

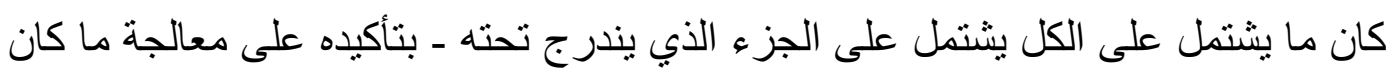

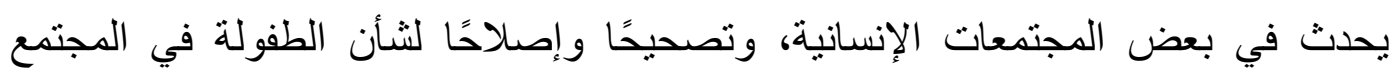

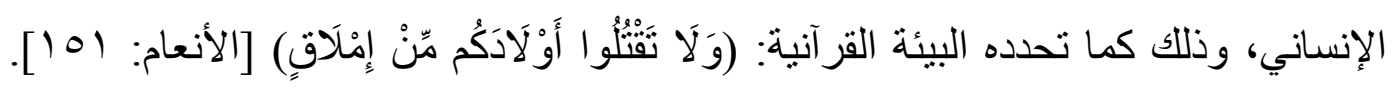

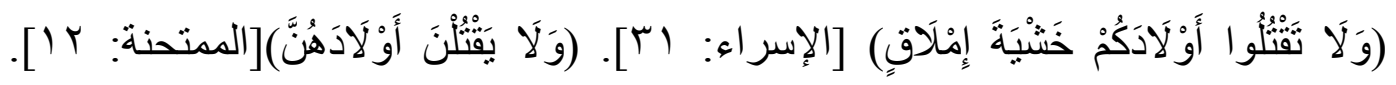




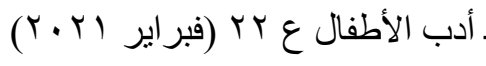

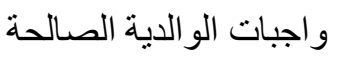

و الإملاق الدذكور في الآيتين: من أملق: افتقر بعد غنى، كأنه أملقَ مالَه و أذهبَه مَكَقَة: محاه وذهب به، والإملاق: الفقر (')

يذكر صاحب "الميزان" قوله: الإملاق: الإفلاس من المال و الزاد، ومنه التملق، وقد

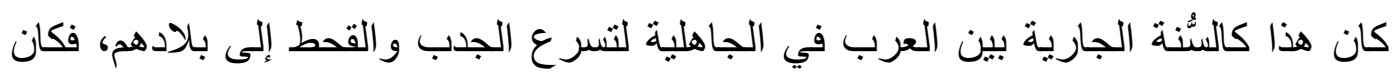

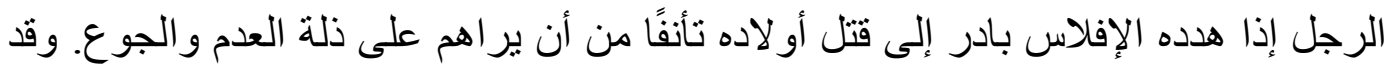

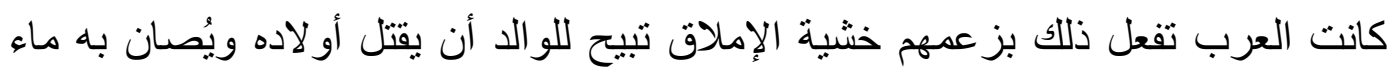

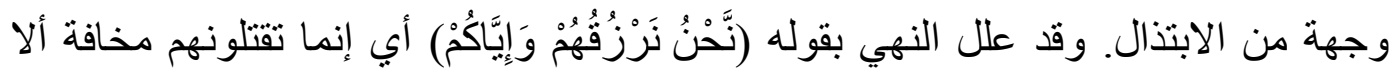
تقدروا على القيام بأمر رزقهم، ولستم برازقين لهم، بل الله يرزقكم و إياهم جميعًا، فلا

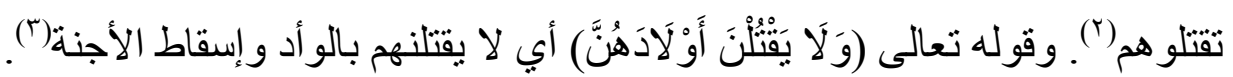

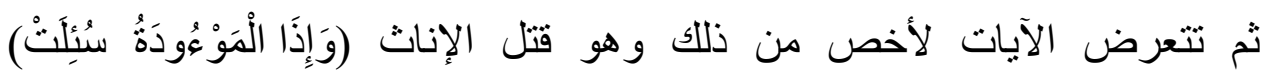

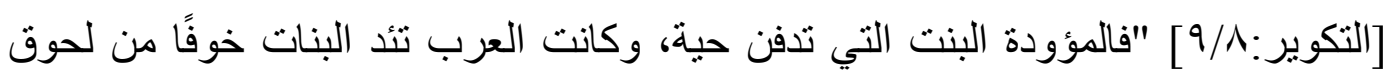
العار بهم من أجلهن. والمسئول بالحقيقة عن قتل المؤودة أبوها الو ائد لها لينتصف منه لئه

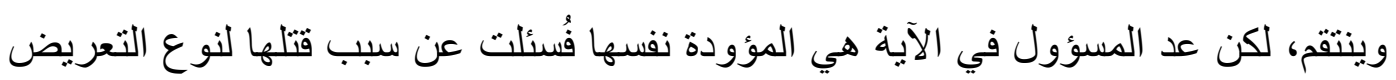

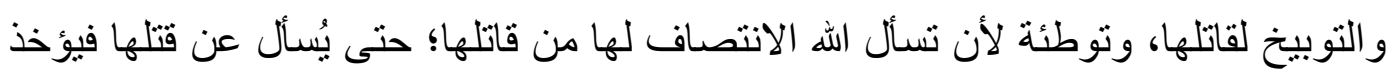
لها منه(๕)

اعتتت البيئة القر آنية بحياة الطفولة و المحافظة عليها، وجاءت محرِّمَةً لما كانت عليه

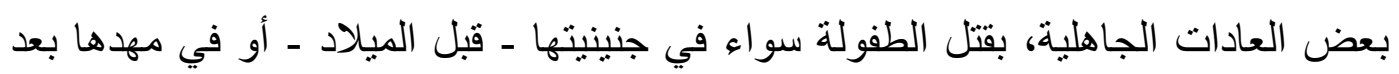

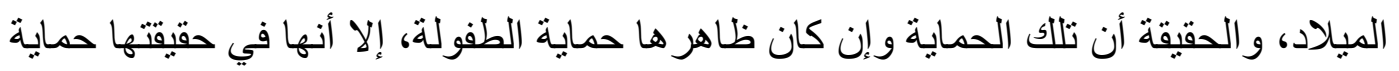
للنوع الإنساني، الذي تمثل الطفولة نواته الجنينية، والتي يريد الله لها أن تستمر إلى ما شاء إهاء

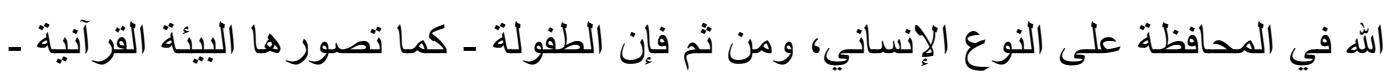

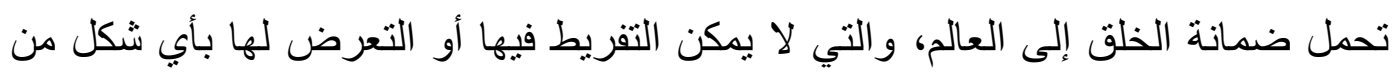
أثنكال انتهاك الحياة، والبيئة القرآنية في ذلك سابقة لكل المعاهدات والاتفاقات الخاصة

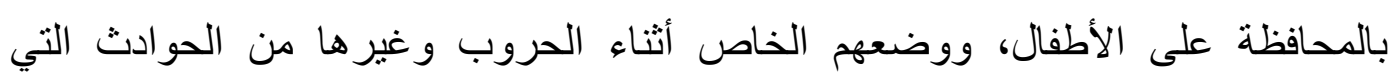

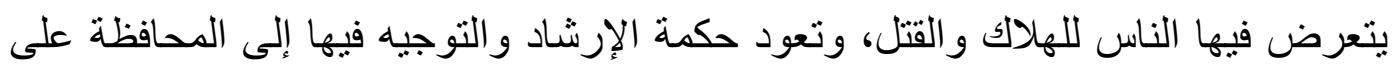

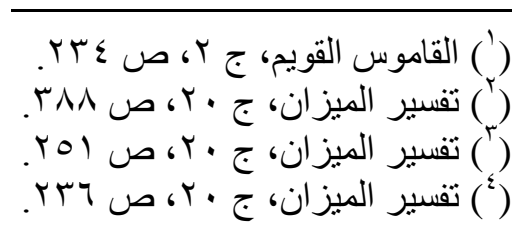




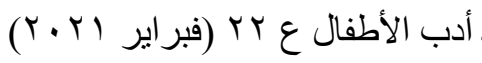
واجبات الو الدية الصالحة

مستقبل النوع الإنساني، فضلً عن الكرامة الفردية للنفس الواجب تقدير ها، والمحافظة عليها، وحمايتها ضد كل أخطار الانتهاكات. الطريق الثالث: ضمان المناخ الآمن للميلاد

أوجبت منظومة القيم القرآنية على الأسرة ـ الزوج بصورة أكثر تحديدًا توفير مناخ آمن لميلاد الطفل وإيجاده إلى الحياة الدنيا، ومن مظاهر ذلك أن الاستثناء الأهم في حالة إنهاء الحياة الزوجية، هو الإنفاق والسكن للمرأة الحامل حتى "تضع" حملها (وَأُوَلاتُ

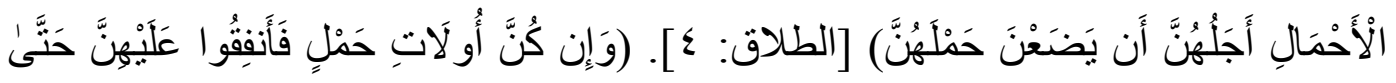
يَضَعْنَ حَمْلَهُنَّ) [الطلاق: 7َ]. فلا خلاف بين العلماء في وجوب النفقة والسكن للحامل المطلقة ثلاثًا أو أقل منهن حتى تضع حملها.. وبسط ذلك وتحقيقه أن الله سبحانه لما ذكر السكنى أطلقها لكل مطلقة، فلمَّا ذكر النفقة قيَّها بالحمل('). ويضمن الثرع هنا توفير مناخ آمن "للولد" سواء من الناحية النفسية أو المادية.

\section{ثانيًا - واجب الحماية الأخلاقية}

و هذا النوع أيضًا من الواجبات القَبْلِية ــ أبي قبل ميلاد الطفل - يمثل حماية أخلاقية

للمولود احترمًا لكر امة النفس الإنسانية القادمة إلى الحياة، وذلك عن طريقين:

\section{الطريق الأول: تحريم الزنا}

أوجبت منظومة القيم القرآنية "الزواج" كطريق وحيد للولد، وللنسل الإنساني، ومن هنا فقد حرمت كل أثكال مجيء النسل غير هذا الطريق، فحرمت "الزنا"، وأوصت بعدم الاقتر اب من كل ما يؤدي إليه، ووضعت سياجًا أخلاقيًا مانعًا لكل ما يُقَرب منهـ. (وَلَا تَقْرَبُوبا

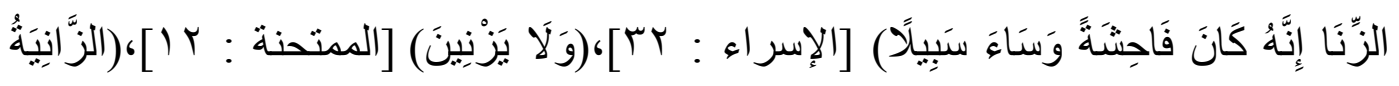

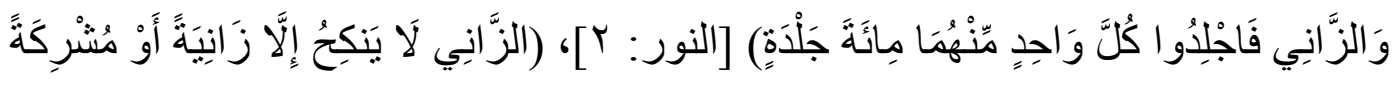

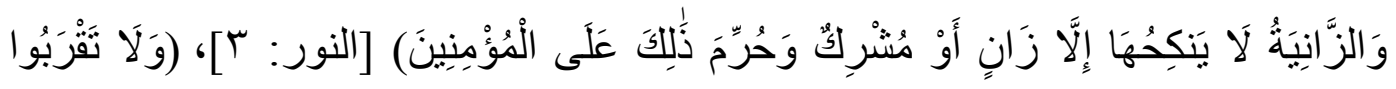

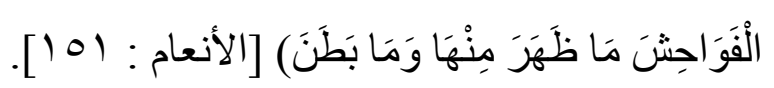

يذكر صاحب الميزان في قوله تعالى [الأنعام: 101 10]. أن الظاهر أن المراد مما ظهر ومما بطن العلانية والسر : كالزنا العلني، واتخاذ الأخدان و الأخلاء سرًا... وفي استباحة

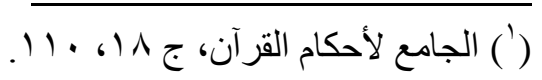




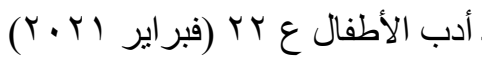
واجبات الو الدية الصالحة

الفاحشة إبطال للاجتماع العام، وفي ذلك شيوعها لأنها من أعظم ما تتوق إليه النفس الكار هة، لأن يضرب عليها بالحرمان من ألذ لذائذها وتُحجب عن أعجب ما تتعلق به وتعزم به شهوتها، وفي شيوعها انقطاع النسل، وبطلان المجتمع البيتي، وفي بطلانه بطلان المجتمع الإنساني الكبير؛ ولذلك بالغ الله تعالى في تحريم الزنا "وَلَا تَقَرَبُو ا" حيث نهاهم عن أن تقربوه، لأنه فاحشة تؤدي إلى فساد المجتمع في جميع شئونه، حتى ينحل عقده، ويختل نظامه، وفيه هلاك الإنسانية(1).

من ناحية أخرى بانفتاح باب الزنا تنقطع الرغبات عن الزواج و الازدو اج؛ إذ لا يبقى له إلا محنة النفقة، ومشقة تحمل الأولاد وتربيتهم، ومقاساة الثدائد في حفظهم، والقيام بالو اجبات المكلفة نحوهم، بينما الغريزة تقنع من سبيل آخر من غير كد ولا تعب، وهو ما جنى ثماره المجتمع المعاصر في الحياة المدنية الغربية، حيث أخذ مواليد الزنا في ازدياد يومًا بعد يوم يقطع منابت المودة والرحمة وتعلق قلوب الأولاد بالآباء، ويستوجب ذلك انقطاع المودة و الرحمة من ناحية الآباء بالنسبة إلى الأولاد. وهجر المودة والرحمة بين

الطبقتين الآباءو الأو لاد يقضي بهجر سنة "الزواج" في المجتمع، وهو ما فيه انقر اضهم(؟). يعاني المجتمع الغربي المعاصر (الأوروبي والأمريكي) من آثار غياب الضوابط القيمية في العلاقات بين الجنسين، مما أدى إلى تفثي ظاهرة "الزنا" وحازت كثيرًا من القبول الاجتماعي، وخضع لدراسات اجتماعية عديدة في علم الاجتماع الغربي المعاصرة، ويسمى "المعاثرة قبل الزواج"، وبصرف النظر عن الجانب الأخلافي في هذه الظاهرة، إلا أن مآلات غياب هذه الضو ابط القيمية يحصد ثمار ها المجتمع الغربي تدريجيًا، بضعف قيمة الأسرة، وضعف العلاقات الو الدية، ومن ثم ضعف شبكة العلاقات الاجتماعية بصفة عامة، ولولا وجود دولة قوية ذات مؤسسات لم يكن لهذه المجتمعات تواجد على المستوى الإنساني، كما تعاني هذه المجتمعات من ضعف الرغبة في الذرية والولد، نتيجة لأن الإشباعات الغريزية الحرة، والتي لا يتبعها مسؤولية الالتزام بنتاج هذا الإشباع تلازم معه ضعف الثعور الوالدي، ومن ثم تعلن الدول الغربية سنويًا طلبات للهجرة من دول العالم للمحافظة على التوازن البشري فيها، ولبناء مجتمع "مهجن" من أجناس متعددة يحملون جنسية تلك الدولة، وتفرض عليهم الالتزام والاندماج المجتمي والتزاوج للاستمرار ضمن شبكة 


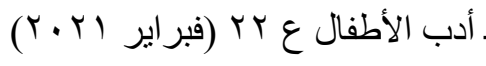
و اجبات الو الدية الصالحة

علاقات المجتمع، وذلك لسد الخلل الناشئ في الأساس من انتهاك الحماية الأخلاقية للجنس البشري وللطفولة خاصة، من خلال فتح آفاق ممارسة الجنس غير المسئول وغير المنضبط بين الجنسين.

الطريق الثاني: التكريم والمساواة

يقوم هذا الطريق على مبدئية تقدير النفس القادمة إلى الحياة، مهما كان نوعها (ذكرًا أو أنثى)، ومن ثم نعى الوحي وندد بأولئك الذين بكظمون بوجو ههم من شدة الحزن إذ سمعوا بأن مولودهم أنثى [النحل: ^1^]. إن تقرير مبدأ المساواة ـ كما أشرنا إليه من قبل - هو مبدأ عام لكل بني الإنسان الذين صدرو ا في خلقهم الأول من "نفس واحدة" وما زالوا يتناسلون حتى اليوم - من هذه النفس - عبر (الذكر والأنثى). ويجعل الوحي "التقوى" هي سمة التفضيل البشري بين الذكور بعضهم البعض، أو الإناث بعضهم وبعض، أو بين الذكور و الإناث [الحجرات: ما'].

\section{ثالثًا - واجب الحماية الاجتماعية}

يتمثل واجب الحماية الاجتماعية هنا في إصلاح العرف الذي كان سائدًا عند العرب عند نزول الإسلام، وهو "التبني"، و الذي كان بموجبه أن يحمل الولد اسمًا غير اسم أبيه سو اء كان معلومًا أو غير ذلك. و التبني ـ لغةً - : اتخاذ الرجل ابن غيره المعروف أو المجهول نسبه كولده، وكان العرب في الجاهلية يجعلون للولد بالتبني (وهو ما يعرف لغةٌّ بالدَّعي) ما للولد الأصيل من حقوق، كأن يحمل اسم المُنَنِني، ويرثه من بعده، ويعتبر من المحارم في الزواج، فلما جاء الإسلام أبطل هذا، وبين السبب في إبطاله [الأحزاب: 0]، وبهذا التشريع القرآني أصبح لا يترتب على التبني أية حقوق بين المتبني والدعي كالتي بين الآباء والأبناء، مثل النفقة والمير اث. كما أن التبني لا يعتبر سببًا لقيام التحريم في عقود الزواج، فالرجل لا تحرم عليه

فتاة تبناها(')

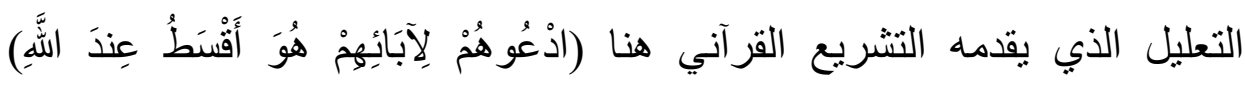
[الأحزاب: 0] هو العدالة في النسب، أي نسب الطفل إلى والده الحقيقي (البيولوجي)، وليس

$$
\text { (') قاموس المصطلحات الإسلامية، ج ب، ص r با . }
$$




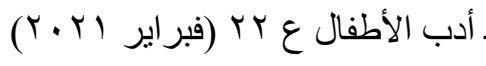
و اجبات الو الدية الصالحة

(الاجتماعي) لو لم يجتمعا. أقسط هنا أي أعدل "حيث رفع الله حكم التبني، ومنع من إطلاق

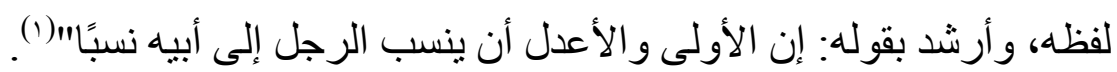
كما يثير ميثاق الطفل في الإسلام في مادته (ع () إلى حق الطفل في النسب في

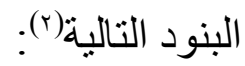
ا. ـ للطفل الحق في الانتساب إلى أبيه وأمه الحقبقيين. r. وتَحْرُمُ - بناء على ذللكـ الممارسات التي تثنك في انتساب الطفل إلى أبويه، كاستئجار الأرحام ونحوه.

r. وتُتَّع في ثبوت النسب أحكام الثريعة الإسلامية.

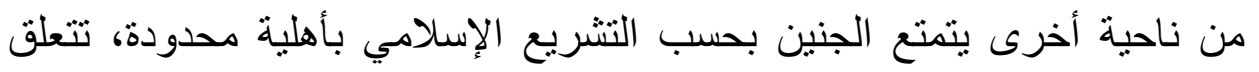

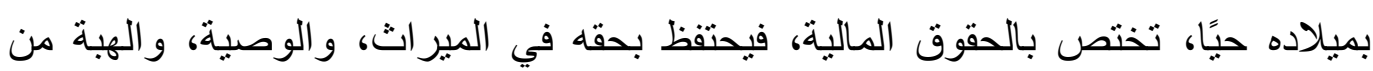

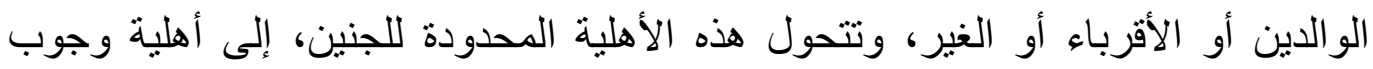
للطفل حال ميلاده، حيث يتمتع بأهلية وجوب كاملة في حقو قله الاقتصادية و الاجتماعية.

$$
\text { رابعًا - واجب البناء الجسدي }
$$

تؤكد البيئة القرآنية على العناية بجسد الطفل منذ ميلاده ـ بل قبل الميلاد ـ فبعد

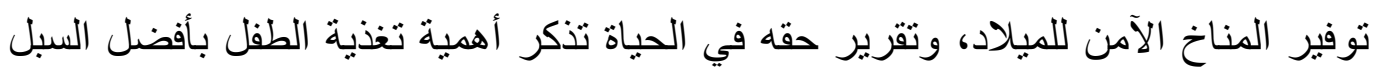

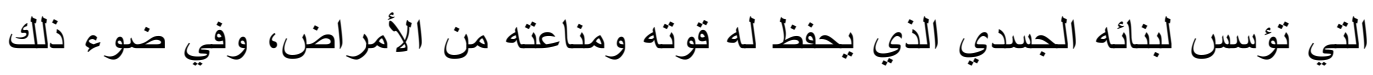
جاءت البيئة القرآنية تقرر القو اعد و الضوابه لبطن التالية:

ا. تحديد مدة الرضاعة بحولين كاملين: (وَالْوَالِدَاتُ يُرْضِِْْنَ أَوْلَادَهُنَّ حَوْلَيْنِ كَامِلَيْنِ)

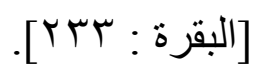

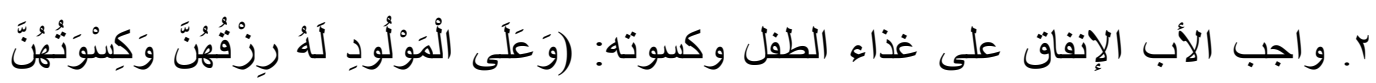

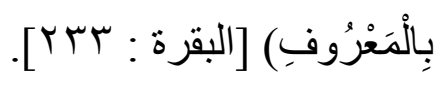

r. كذلك تثثير البيئة القرآنية إلى أن الفطام في أقل من حولين لا يجوز إلا عند رضا

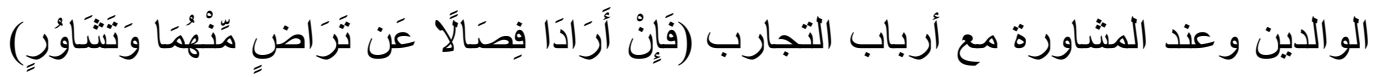

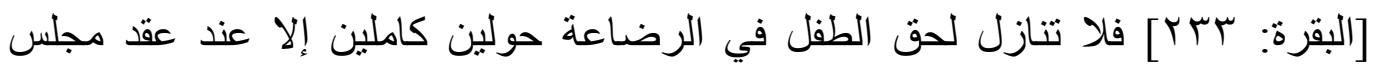




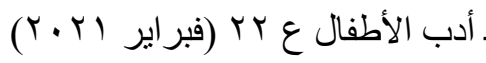

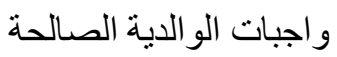

يتشاور فيه الزوجان، يتوصلان من خلاله إلى عدم ضرر الطفل في ضوء الآراء الخبيرة،

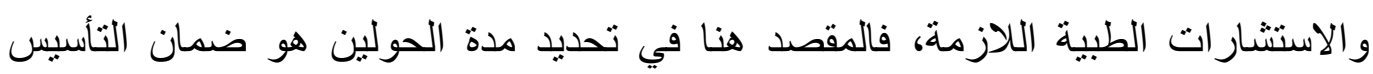

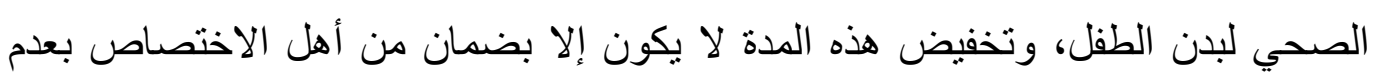
تأثر هذا المقصد.

إن مسألة الفطام في أقل من الحولين جاء التأكيد فيها على فكرة "التشاور" قبل

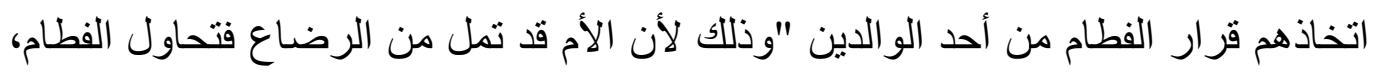

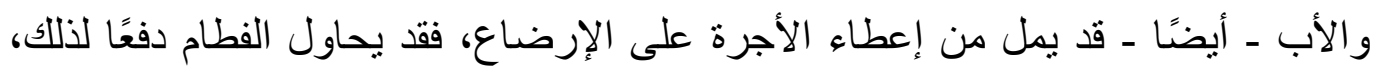

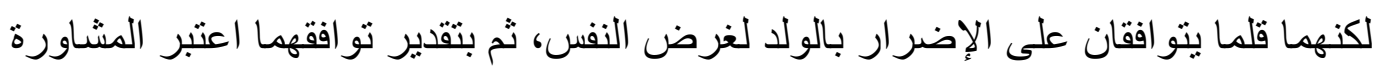

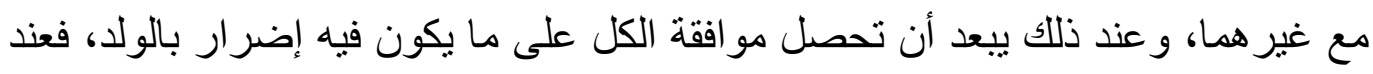
اتفاق الكل على أن الفطام قبل الحولين لا يضره البتة، ثم عند اجتماع كل هذه الثر ائط لم لم يصر ح بالأذن، بل قال: لا جناح عليكم" (1). إن واجب الرعاية الجسدية تسبق في أدائه والقيام به "الأم" خاصة في المراحل

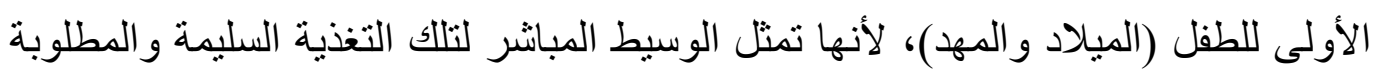

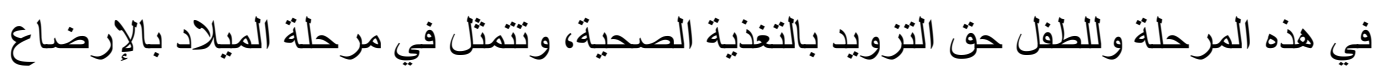

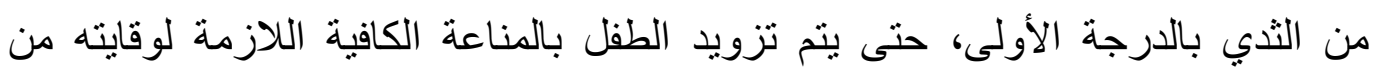

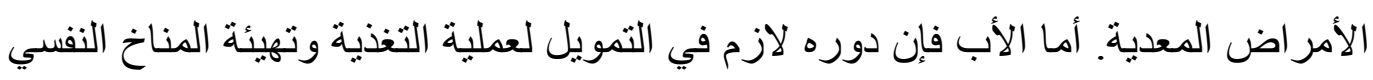
لمكان القيام بتلك العملية، وهو السكنى التي يجب أن تراعي توفير النواحي الصحية لنمو

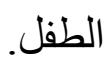

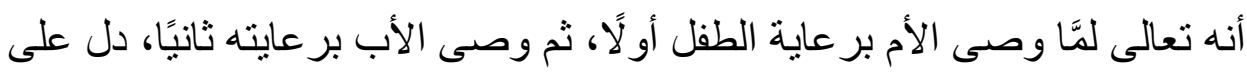
أن احتباج الطفل إلى رعاية الأم أثند من احتياجه إلى رعاية الأب؛ لأنه ليس بين الطفل

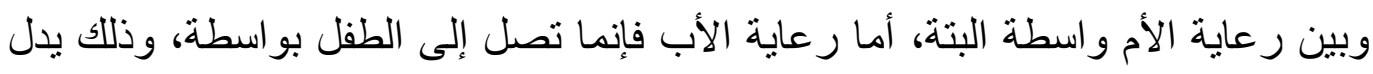
على أن حق الأم أكثر من حق الأب في الطفل(r).

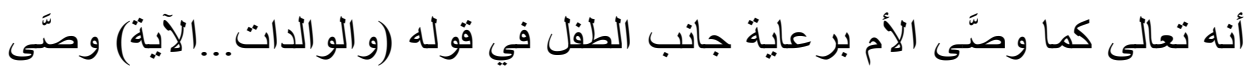
الأب برعاية جانب الأم، حتى تكون قادرة على رعاية مصلحة، فأمره برزقها وكسوتها

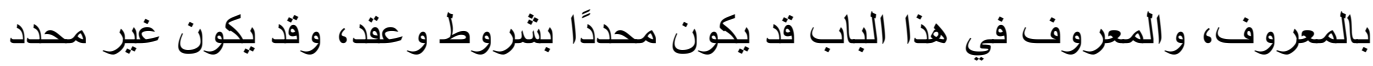




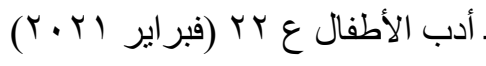
واجبات الو الدية الصالحة

إلا من جهة العرف؛ لأنه إذا قام بما يكفيها في طعامها وكسوتها، فقد استغنى عن تقدير الأجرة، فإنه إن كان ذلك أقل من قدر الكفاية لحقها من الجوع والعري، فضرر ها يتعدى إلى لى

وتستمر وصية الوحي بالطفل حتى في غياب مصدر الإنفاق (الأب) بالوفاة، فيؤذ

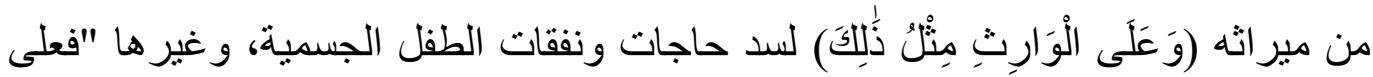
الوارث عند الموت، مثل ما على الأب للمرضع من النفقة والكسوة، ويعني بالوارث: الولد الذي يرضع، أن يؤخذ من ماله - إن كان له مال ـ أجر ما أرضعته أمه، فإن لم يكن للمولود مال و لا لعصبته فليس لأمه أجر، وتجبر على: أن ترضع ولاها بغير أجر "(؟). وتشير الدراسات الحديثة إلى أهمية "الإرضاع" المباثر من الأم، و أثره الطبي و النفسي لدي الطفل "فالتغذية من ثدي الأم أهم رابطة توثق العلاقة بين الطفل وأمه، و الإبقاء على هذه العلاقة في أحسن حال لها. و التغذية من الثذي هي الخطوة المنطقية التالية بعد التغذية التي كانت تتم عن طريق المشيمة، فهي عملية طبيعية، وتجاهلها يؤدي إلى الإضر ار بتطور الطفل ونموه على أحسن وجه"(َ).

وقد قررت الثريعة بقاء المرأة المطلقة في السكن إذا كانت حامل، وأوضحت بشكل لا لبس فيه أن النفقة واجبة لها ولحملها [الطلاق:؟]، [الطلاق: ؟]، وقد أوضحت الدراسات الحديثة إلى أن مسألة "التغذية" كأحد وجوه الإنفاق ـ هنا ـ على المرأة الحامل تعد "من أهم المؤثرات البيئية الفعالة في حياة الجنين قبل ولادته وبعدها، إذ أنه بواسطة الطعام الذي تتناوله الأم الحامل تستطيع أن تؤثر في نمو طفلها الجنين بشكل عميق ومستديم قبل الو لادة وبعدها، حيث أوضحت المشاهدات ـ بشكل عام ـ أن الأم المتمتعة بصحة جيدة وتتناول الأطعمة المناسبة، فإنها تحمل وتلد طفلً يتمتع بينية قوية ومظهر جيد، وعلى العكس من ذللك فإن من المشاهد أن الأم التي تعاني من سوء في التغذية فإنها تضع دائمًا طفلًا ضعيفًا وشاحبًا، ويعاني من الأمر اض" (ع). إن حفظ الجسد من المقاصد الرئيسة في الإسلام لحفظ الحياة عامة من ناحية، ولتأدية واجبات العبادة والعمران للمكلفين من ناحية أخرى، وتقوم تعليمات الإسلام على

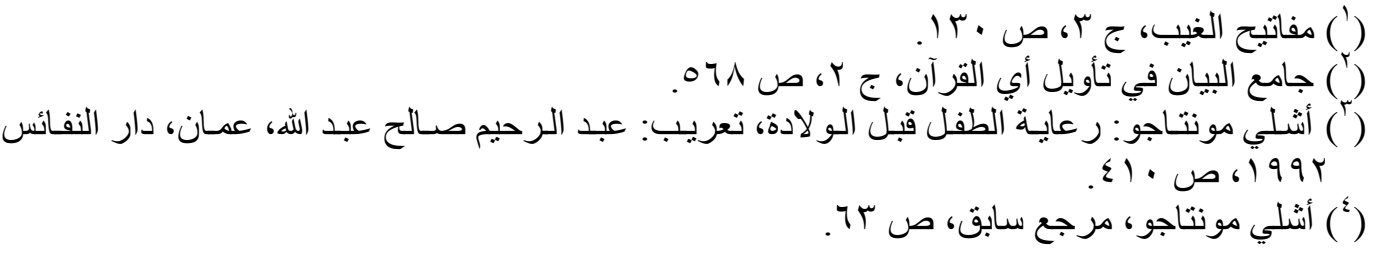




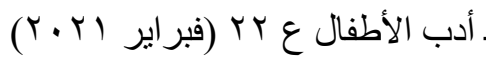
واجبات الو الدية الصالحة ــ

أساس حفظ وسلامة البدن، والسبب في حرمة الكثير من الأمور هي أنها مضرة بالبدن،

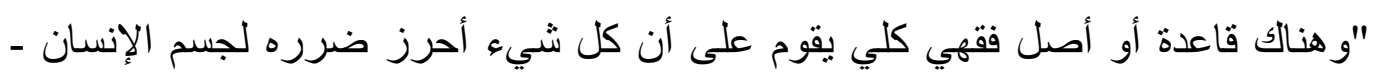

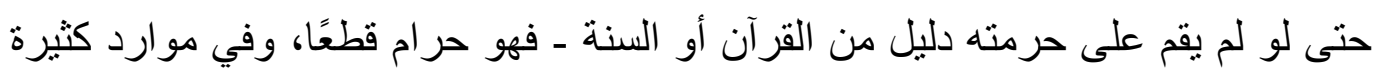

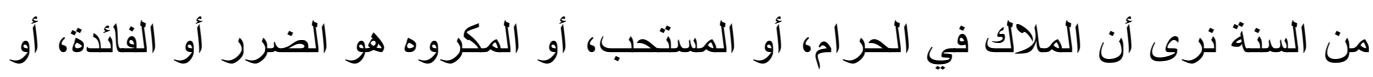

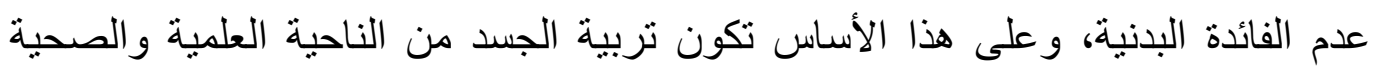

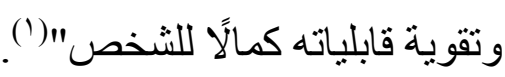

\section{خامسًا - واجب التربية العقدية}

العناية الوالدية للطفولة ولأعضاء الأسرة الجدد لا تقتصر في المنظور التوحيدي

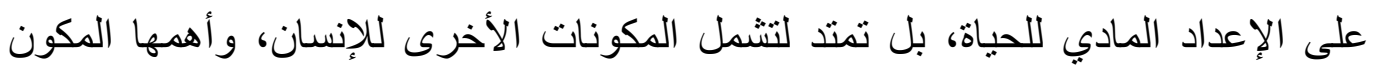

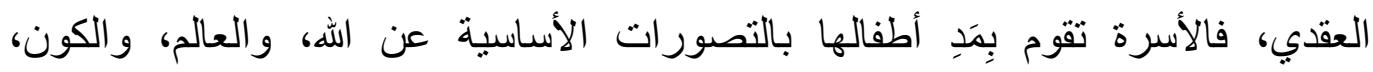
و الإنسان، و المصير ، وتنقل الاعتقادات ـ بما تتضمنه من مفاهيم وتصور الات ـ إلى أعضائها

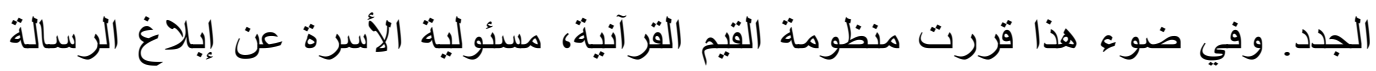

الإلهية لأبنائها.

ومنذ البدء حددث تلك المنظومة غاية التقاء الزوجين وجلب الذرية هو تحقق التقانق

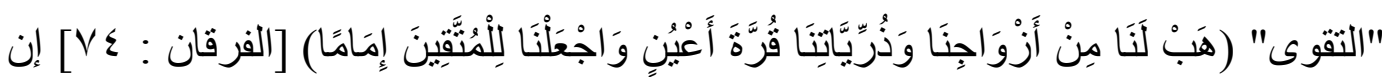

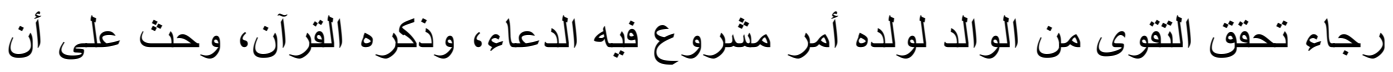

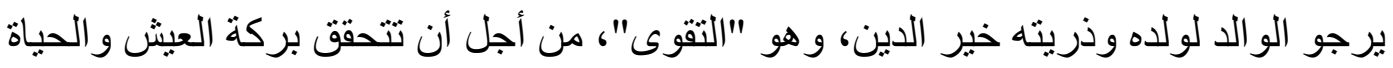

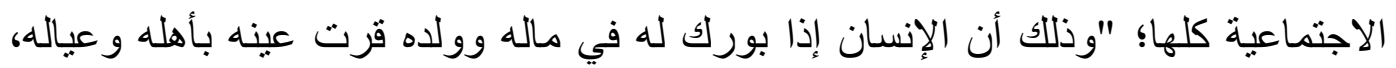

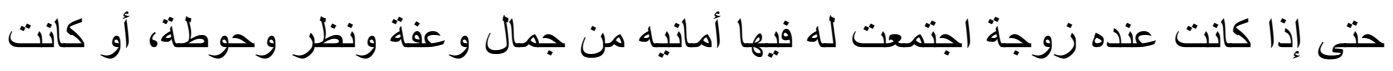

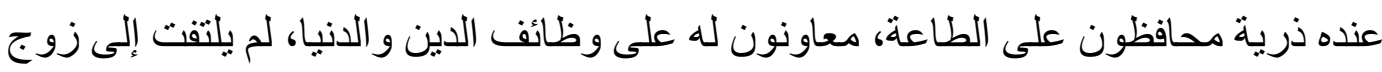
أحد ولا إلى ولده، فتسكن عينه عن الملاحظة، و لا تمند عينه إلى ما ترى، فذللك حين قرة

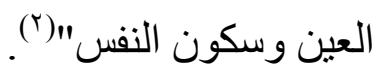

وثُفصيل ذلك في موقع آخر بالتوصية بالتربية على التزام النهج الإلهي عن طريق

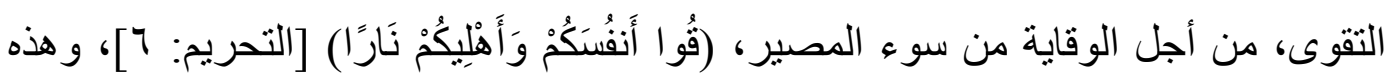




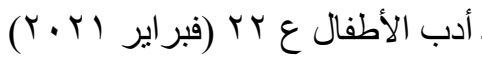
و اجبات الو الدية الصالحة

التقوى تكون من الوالدين للأبناء، وذلك بتوجيههم نحو الهذى، وصوب الحق، وناحية الإسلام.

قال قتادة ومجاهد في كيفية هذه الوقاية "...على الرجل أن يُصلح نفسه بالطاعة، ويصلح أهله إصلاح الر اعي للرعية، يأمر هم وينهاهم. وقال بعض العلماء (قُو أَنَفْكُمْْ) دخل فيه الأو لاد لأن الولد بعض منه، فيعلمه الحلال والحر ام، ويجنبه المعاصي والآثام، إلى غير ذللك من الأحكام. وقيل: نقي أهلينا: نُعلم أو لادنا وأهلينا الدين و الخير "('). ومن جوانب التربية العقدية التي وردت في البيئة القرآية الموجهة إلى الطقولة: - - التوحيد ونبذ كل ألوان الثرك [لقمان:با I]].

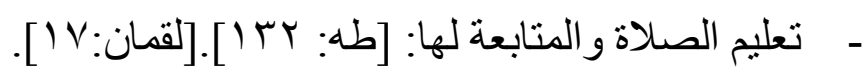

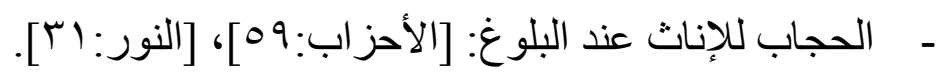
- الأمر بالمعروف والنهي عن المنكر [لقمان: IV]]. سادسًا - واجب الإنفاق المادي الإنفاق من النفقة: اسم لما يُنفَقَُ من المال وغيرهُ، وجاءت مواضع الإنفاق على الأسرة في البيئة القرآنية في موضعين [النساء: ع؟]، [الطلاق:V]. . وقد أجمعت الكتابات الفقهية على أن الإنفاق على الأسرة في كل مراحلها واجب على الأب، وهو أهم الواجبات الأساسية للوالدية، والإنفاق هنا يثمل ما تحتاجه الأسرة و أعضاءها من طعام وكسوة وما يلزم الحياة الكريمة، وبهذا فليس على المرأة ولا الأطفال العمل لسد احتياجاتهم. إن مسئولية الإنفاق هي مسئولية الزوج في المقام الأول، فهو ملزم بسد الحاجات المالية للأسرة، ولكن في الوقت الحاضر ومع خروج النساء وحصولهن على دخل خاص بهن، فيستحب أن يسهمن في الإنفاق مع أزواجهن، إذا لم يكن دخل الزوج كافيًا للإنفاق على الأسرة، وبذلك تعيش الأسرة حياة مستقرة يسودها الود و التر احم(؟). ومن الناحية القيمية الوالدان مسئو لان عن أولادهما، وكفالة الحياة الطيبة لهم: ماديًا و معنويًا، بتيسير مطالبهم، و المحافظة عليهم، وتوفير وسائل العيش الكريم لهم، بحيث يتو افر 


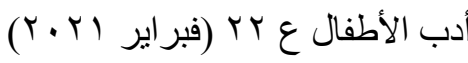

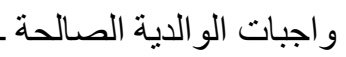

لهم احتياجاتهم من مأكل، ومشرب وملبس، وعلاج، وذللك وفق استطاعة الأسرة وقدرتها الاقتصادية، من دون إسر اف أو تقتير.

وقد حدد ميثاق "الطقل" في الإسلام في المادة (IV) وجوه النفقة الوالدية والية والاجتماعية

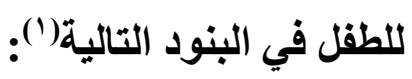
1. لكل طفل الحق في مستوى معيشي ملائم لنموه البنني، والعقلي، والديني، و والاجتماعي. r. ويثبت هذا الحق للطفل - الذي لام الله - على أبيه، ثم على غيره من أقاربه الموسرين، وفقًا لأحكام الثريعة الإسلامية.

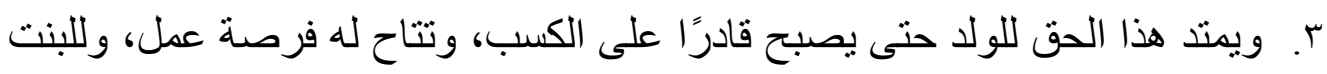
حتى تنزو ج، أو تستغني بكسبها. ؛. و على مؤسسات المجتمع كافة، ومنها الدولة مساعدة الوالدين وغيرهي هما من الأشخاص المسؤولين عن الطفل، في تأمين ظروف المعيشة اللازمة لنموه.

\section{سابعًا - واجب تنمية القابليات العقلية}

من واجبات الو الدية الصالحية التهيئة العقلية لأبنائها - لا سيما في السنوات الأولى وذلك عن طريقين: الأول: اكتشاف احتياجات المعرفة عند الطفل في مر احل نموه، و الثاني: تلبية الاحتباجات العقلية لكل مرحلة من مراحل نموه من خلال المحيط الأسري الخاص

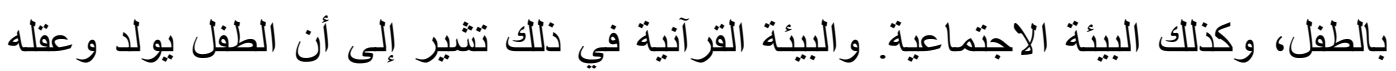
(المعرفي) صفحة بيضاء، بينما بمتلك الوسائل اللازمة لتحصيل المعارف بشقيها:

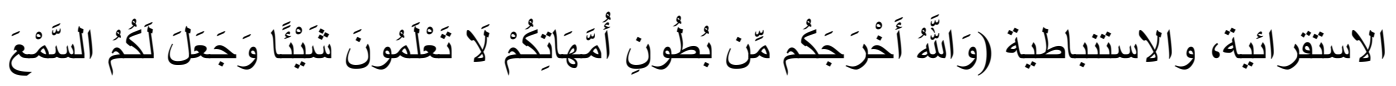

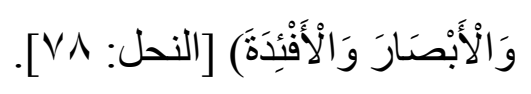

وتبدو أهمية هذا الواجب؛ لأنه يحقق مقصد رئيس من مقاصد التوحيد الإلهي، وهو حفظ العقل الإنساني؛ لأنه مناط التكليف في الاعتقاد والعبادة، وبه يُنينى الاعنقاد الصحيح بالنظر والتأمل في الكون؛ لذلك حرص الإسلام دائمًا على تنبيه العقول الغافلة، والعقول المقلّة على عمى، والجمود على الموروث لأنه موروث، وليس لأنه حق. فوجه الإسلام 


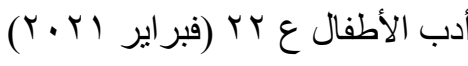
واجبات الو الدية الصالحة

العقل نحو وظائفه التي تتعدى مجرد حرية التفكير إلى الأمر بهذا التفكير، واعتباره ضرورة

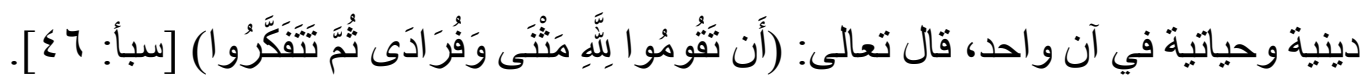
ومن مقاصد الثريعة حفظ العقل، ومن حفظ العقل: نهيه عن التسليم بالأحكام دون

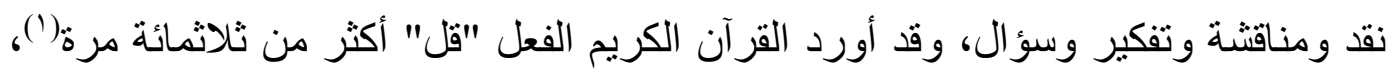

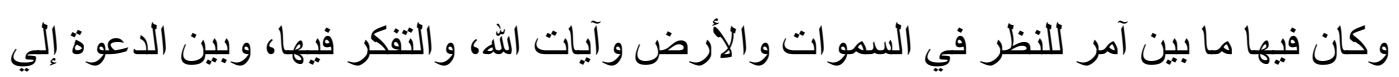
التعرف على الكتب السماوية السابقة وفحصها وتمحيصها، والإجابات عن أسئلة ـ

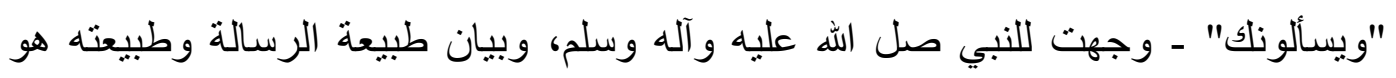

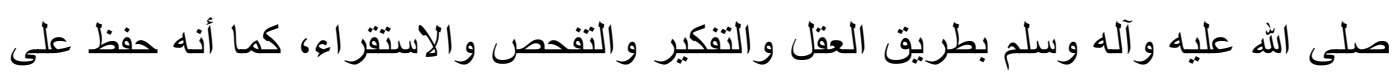
العقل حيويته و انتباهه وقوته، فحرم عليه الخمر وكل ما يذهب بهذه القوة أو تلك الحيوية. يمثل القرآن الكريم مصدرًا مهمًا للتوجيه لتتمية القابليات العقلية لدى الطفل

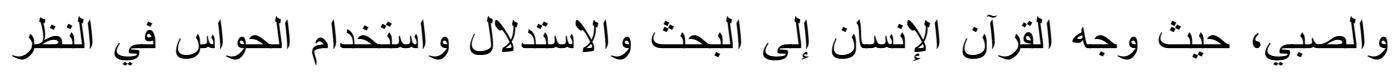

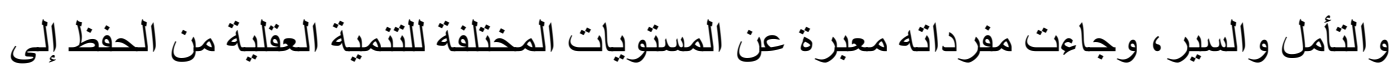
التذكر و الفقه والتدبر، كما دعا إلى الاحتكام إلى التجربة و الاستقر اء في إصدار الأحكام. وعى القرآن عملية التنمية العقلية وآفاقها في تتكيل الوجدان الإنساني الذي لا بد أن

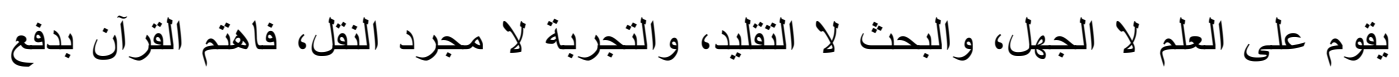

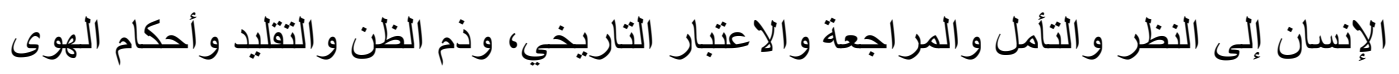

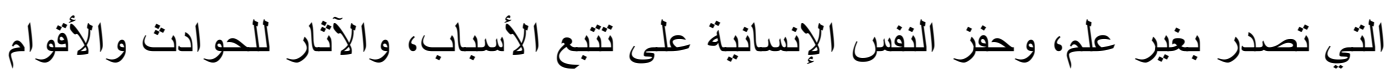

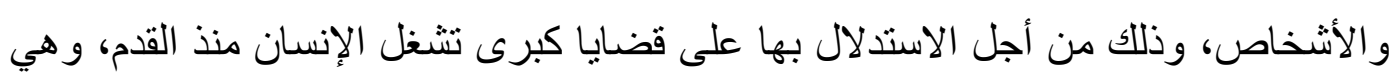
قضايا الخلق و الوجود و المصير.

إن القر آن لم يترك الإنسانَ عبثًا يتيه مع التائهين، أو يهيم على وجهه عابثًا أو ماجنًا

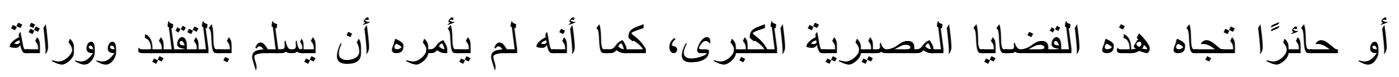

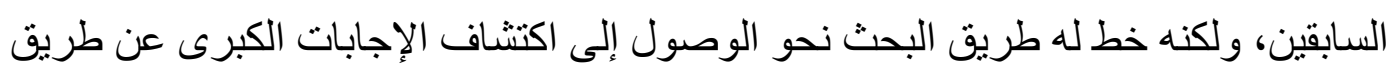
عقله الذي منحه الله إياه، ومن أدوت التفكير التي حض القرآ آن على استخدامها (الحواس، و العقل، و الحس، و التجربة....).

(') محمد فؤ اد عبد الباقي، مرجع سابق، ص TVV - TIN. 


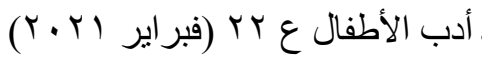
واجبات الو الدية الصالحة

إن مفردة "السير" ـ على سبيل المثال ـ الواردة في البيئة القر آنية التي تتعلق بتنمية القابليات العقلية، و التي ترتبط بالنظر و التأمل يمكن أن تطر ح هذه المعادلة القر آنية في توجيه الإنسان إلى الاستدلال بمعناه الحضاري و المعرفي والتاريخي، هذه المعادلة تتضمن الصيغة التالية: السير + النظر = الاعتبار، فالسير والنظر يؤديان إلى الاعتبار، وتحصيل العبرة لأولي الألباب [آل عمران/ • 19$]$ ]: أي ذوي العقول الراجحة التي استخدموها بما بؤدي بهم إلى معرفة حقه، بحال ومصير الإنسان في ضوء الحوادث الواقعة تارة، أو تؤدي به إلى تعديل تصور اته صوب الخالق جل و علا. ويسبق السير النظر، فلا نظر لقاعدة أو راكن عن سبق الكون في الرغبة عن الاكتشاف وإعمال العقل فيما يبني المعارف و العقائد الحقة لدى

ذكرت مفردة "السير" - على سبيل المثال ـ في (ع ا) موضعًا في القرآن - اقترن

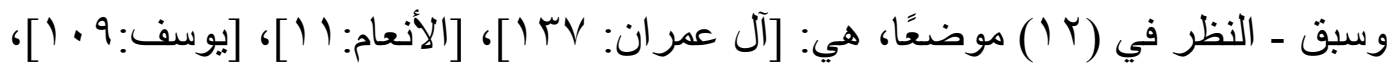

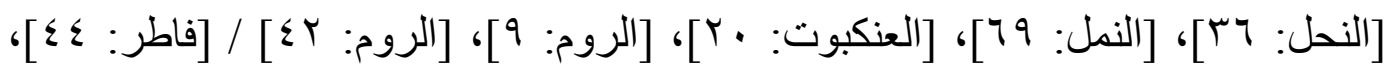

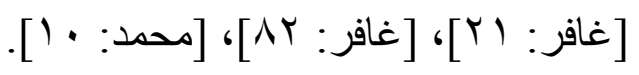

وق تتوعت مجالات السير والنظر في القرآن، منها: ا ـ النظر في أحو ال الأمم السابقة.

r. النظر في سنن التاريخ ومصائر المستبدين و الضالين و الطو اغيت. r. اكتشاف سنن الله في الخلق. ع. الو عي بحقيقة القوة البشرية في مقابل قدرة الله غير المحدودة. ๑. الوقوف على سنن قيام الحضار ات وسنن انحطاطها وسقوطها. من الجدير بالذكر هنا في مجال تنمية القابليات العقلية أن تتعدد مصادر الثقافة الوالدية فيما يتعلق بهذا الإعداد، ومن أهم هذه المصادر: القرآن الكريم، والسنة النبوية، وروايات الأئمة، والتراث التربوي الإسلامي، و النظريات التربوية المعاصرة، والاستفادة من كل ما توصلت إليه العلوم التربوية الحديثة و النظريات و التجارب في مجال التنمية العقلية للطفل، وأن يكون الآباء على وعي بهذه التطورات الحديثة وكيفية توظيفها في البيئة الإسلامية للطفل. 


\section{ثامنًا - واجب التربية الجنسية}

يتحدد هذا الو اجب منذ بلوغ الأطفال، و البلوغ مرحلة من مر احل النمو الإنساني التي تضمنتها البيئة القرآنية، حيث حددث عدة مراحل للنمو للإنساني وهي: الجنين، والمهد، و الطفولة، والبلوغ، و الرشد، والثيخوخة، والكهولة، وتتميز مرحلة البلوغ بالنمو الجسمي و العقلي، وهي في الإسلام مناط التكليف، وأداء الواجبات المقررة شرعًا. وجاءت البيئة القرآنية معبرة عن "البلوغ" كمرحلة نمو بهذا المعنى في المواضع التالية: (وَإِذَا بَلَغَ

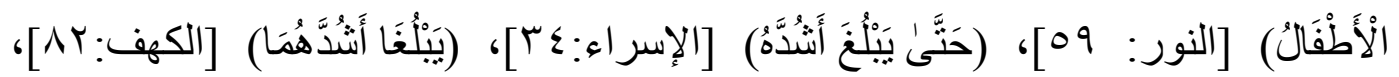

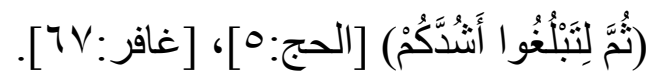

و البلوغ - لغة -: يقال بلغ بلوغًا أي وصل إليه أو قاربه،...وبلغ الغلام أي أدرك...و البلوغ - هنا ـدخول الصبي و الصبية مرحلة (البلوغ الجنسي) ولها علامات، منها ما هو مشترك بين الذكر و الأنثى. ومنها ما هو خاص بالأنثى دون الذكر، أما ما هو مشترك بين الذكر والأنثى فهو: خروج المني من ذكر الرجل وقُُبّل المر أة في يقظة أو منام، وإنبات الشعر الخشن حول ذكر الرجل وفرج المرأة. أما ما هو خاص بالأنثى فهو: إتبان

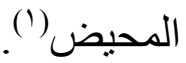

ومن التعاليم الواجبة التي ينبغي أن تقوم الوالدية الصالحة بأدائها نحو الأبناء في ميدان التربية الجنسية، ما يلي:

1. التعريف بمرحلة البلوغ أو التكليف التي يصل إليها الأطفال ومتطلباتها. ץ. تعليم البالغين الاغتسال من الجنابة. r. تعليم الأنثى وقت الحيض، وطريق معرفته، ووقت زواله، وكيفية التطهر منه، وما يترتب على ذللك من واجبات الصوم و الصلاة الفائتة المفروض منها، و غير ذلك. ؟. تعليم المحاذير (العبادية) للجنابة والحيض. •. ت تعليم التقرقة في المضاجع بين الذكور و الإناث، ودلالة ذلك الاجتماعية والأخلاقية. 7. التذريب على السلوك الاجتماعي للبالغين قبل الوصول إلى هذه المرحلة. V. ت تعليم آداب الاستئذان و الدخول على الو الدين. 


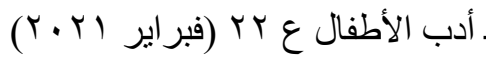
و اجبات الو الدية الصالحة

^. التربية على الهوية الثخصية، من خلال مفهوم (الجنس)، فالأنثى لها خصائصها التي ينبغي أن تتميز بها، وهو ما تضطلع به الأم داخل الأسرة باعتبار ها الأقرب لاحتياجات الأنثى. وكذللك فالذكر داخل الأسرة له هويته الاجتماعية التي ينبخي أن يتعلهها في ضوء بلوغه (الجنسي) وهو الواجب على الأب أن يكون مرشدًا اجتماعيًا ونفسيًا رائدًا لابنه في هذه المرحلة. 9 9. كذلك - أيضًا - فإن التربية الجنسية للأبناء داخل الأسرة تختلط أو تتكامل مع أنماط التربية الوجدانية والاجتماعية والأخلاقية، وهو ما يتطلب الوعي الثامل بجوانب النمو لمرحلة البلوغ وأبعادها في حياة الذكر أو الأنتى دن الأولاد داخل

$$
\text { الأسرة. }
$$

• ( . تكوين اتجاهات صحيحة لدى الأبناء نحو هوياتهم الجنسية. 1 ا إكساب البالغين خبرات صالحة تحفظهم من الخبرات المنحرفة نحو طبيعة المرحلة

$$
\text { الجديدة. }
$$

r ا .تعليم البالغين أهم الو اجبات الفقهية والاجتماعية التي تترتب على هذه المرحلة. ץ ا..غرس قيمة "المسئولية" الدينية والاجتماعية للبالغين وتوعيتهم بها، وارتباطها بمرحلة "البلوغ" لديهم. ع ا ـ بناء قيم "أخلاقية" نحو الجسد وتغير اته لدى البالغين. 1. توجيه البالغين نحو اكتشاف "الواجبات" الدينية لهذه المرحلة بأنفسه، وتجنب "التلقين" المباثر.

ولغرس هذه التعاليم والتدريب عليها، يكون على الوالدين تحقيق عدة متطلبات ثقافية،

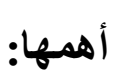
- الوعي بجوانب "التربية الققهية" اللازمة لهذه المرحلة، و التعريف بكيفية تقديمها للأبناء و البالغين. - الوعي بالأبعاد النفسية، الوجدانية وطرق الاحتواء، والاستيعاب النفسي للتغير ات و الاضطر ابات المحتمل حدوثها عند الأبناء في مرحلة البلوغ. 


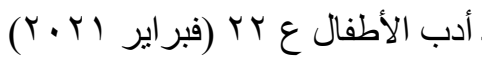
و اجبات الو الدية الصالحة

- الوعي الاجتماعي والأخلاقي اللازم، وغرس القيم اللازمة لهذه المرحلة عند الأبناء، وذللك لمساعدتهم على خفض التوترات، وتجنب الانحر افات السلوكية و غير ها.

ومن أجل قيام الوالدين بدور هم العلمي و الديني والتربوي في هذه المرحلة لأداء هذا الو اجب يمكن للوالدين الاستعانة بالكتابات الفقهية والتربوية والنفسية المتخصصة في هذا الميدان، ولهذه المرحلة.

\section{تاسعًا ـ الوقاية من الانحر افات الجنسية}

أككت البيئة القرآنية على ضرورة تجنب الثهوات التي تحرف الإنسان عن طريق الهداية، وهنا تبدو مسئولية التنشئة الأسرية في تزكية أفرادها وهدايتهم، ومما يساعد على تحقيق التزكية في التربية الجنسية "الوقاية"، ومن أشكال الوقاية ووسائلها التي يجب أن يقوم بها الوالدين نحو أبنائهم ما يلي('):

ا. التربية الدينية والأخلاقية للأولاد: أي تعريف الأولاد بالقيم الدينية والفضائل الأخلاقية، سواء من الناحية النظرية أو من الناحية العملية. فعندما يخضع الطفل لعملية التعليم الديني و الأخلاقي، فإنه يتأثر و إلى حدود بعيدة بسلوك و أخلاق و الديه، و هذا ما يجعله يحمل قدرة وقوة تمكنانه من التغلب على الانحر افات.

r. رقابة الوالدين على سلوك الأبناء: تشير التعاليم الإسلامية إلى الوقاية من تعرض الأبناء لمشاهدة المناظر الإباحية على الإطلاق، لما لهذا الأمر من آثار غير عادية في ميل الأطفال نحو الانحر اف. ومن كل ما يؤدي إلى ذلك. ". مساعدة الأبناء في تشكيل الأسرة: وذللك بتهيئة مقدمات الزواج، وتسهيل مستلزماته، و الامتناع عن اعتماد شروط معقدة، وتحدثت بعض الروايات عن أن رفض الوالدين زواج الأبناء بسبب الظروف الاقتصادية تؤدي إلى ما عُبر عنه في الروايات بالفتنة والفساد الكبير في الأرض. 


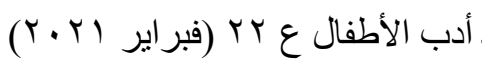
واجبات الو الدية الصالحة

\section{تعليم سورة النور}

من ضروريات التربية الجنسية تعليم سورة "النور" لكل أفراد الأسرة، نظرًا لما تتضمنه هذه السورة من تعليمات وإرشادات بالغة الأهمية في المجالين: الديني، والاجتماعي للمسلم، ولا توجد سورة في القرآن تبدأ بذكر فرضية ما فيها، وفرضية تعلمها إلا سورة النور.

و المحور الذي تدور عليه السورة كلها هو محور التربية التي نتند في وسائلها إلى درجة الحدود وترقى إلى درجة اللمسات الوجدانية الرقيقة، التي تصل القلب بنور الله وبآياته المبثوثة في تضاعيف الكون وثنايا الحياة. و الهدف واحد في الثدة واللين. هو تربية الضمائر، و استجاثـة المشاعر، ورفع المقاييس الأخلاقية للحياة، حتى تشف وترف، وتتصل بنور الله. وتتداخل الآداب النفسية الفردية، وآداب البيت والأسرة، و آداب الجماعة والقيادة بوصفها نابعة كلها من معين واحد هو العقيدة في الله(1). وقد تضمنت "سورةالنور" مجموعة من المحاور التعليمية والتربوية تتعلق بالعلاقات بين الجنسين (الذكر، و الأنتى) والحدود و القيم الأساسية التي يجب أن تحكم تلك العلاقات، ينبغي أن تكون مصدرًا مهرًا للتربية الجنسية في الأسرة، وأهم هذه المحاور ما يلي: ا ـ أحكام وحدود (القذف والزنا)، و التأكيد على قيم: الصدق، و التثبت و التبين في القطع

$$
\text { بتلك الحدود. }
$$

r. تفعيل قيم "الاستعفاف" لمن لا يقدر على تكاليف الزو اج، ومسؤولياته المادية.

$$
\begin{aligned}
& \text { r. آداب دخول البيوت. } \\
& \text { ـ. غض البصر. } \\
& \text { ○. حفظ الفر ج. }
\end{aligned}
$$

7 ـ إبداء الزينة: شروطها و آدابها.

$$
\text { ^. ^. ^. الحجاب وفرضيته. }
$$

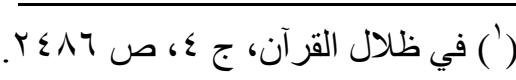




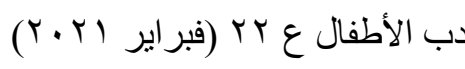
و اجبات الو الدية الصالحة • إداب الاستئذان ـ للأو لاد ـ في الاخول على الوالدين. 11 ( مباحات التو اصل القرابي / الاجتماعي (مع الإخوة والأخوات، و الأعمام و العمات،

$$
\text { r و الأخو ال و الخالات، و الأصدقاء). }
$$

\section{خاتمة}

قدمنا في هذا البحث المختصر أهم واجبات "الو الدية الصالحة" في ضوء المنظور القرآني لوظائف الوالدية تجاه الأبناء، وهو إطار من الحماية الوجودية والأخلاقية والتعزيز العقلي والقيمي، والتطوير النفسي والحفز التربوي للطفولة، يحتاج إلى وعي المؤسسات الفاعلة في مجال الطفولة بدءًا من الأسرة حتى المدرسة والإعلام و المر اكز الثقافية المهتمة بالطفولة بشكل عام، و أن تتحول هذه الواجبات إلى برامج ثقافية لتحويل تللك القيم إلى ثقافة مجتمعية تؤطر فيها حياة الطقولة ونشاطها.

\section{حق ولدك}

و أما حق ولاك، فتعلم أنه منك ومضاف إليك في عاجل الدنيا، بخيره وشره، و إنك مسئول عما وليته من حسن الأدب، و الدلالة على ربه، و المعونة على طاعته فيك وفي نفسه، فمثاب على ذلك ومُعاقب، فاعمل في أمره عمل المتزين بحسن أثره عليه في عاجل الدنيا، المعذور على ربه فيما بيزلك وبينه، بحسن القيام عليه، والأخذ له منه. [الإمام على بن الحسين، رسالة الحقوق] 